\title{
HDAC inhibitors suppress the proliferation, migration and invasiveness of human head and neck squamous cell carcinoma cells via p63-mediated tight junction molecules and p21-mediated growth arrest
}

\author{
AKITO KAKIUCHI $^{1,2^{*}}$, TAKUYA KAKUKI ${ }^{1}$, KIZUKU OHWADA $^{1,2^{*}}$, MAKOTO KUROSE $^{1}$, ATSUSHI KONDOH ${ }^{1}$, \\ KAZUFUMI OBATA ${ }^{1}$, KAZUAKI NOMURA ${ }^{1}$, RYO MIYATA ${ }^{1}$, YAKUTO KANEKO ${ }^{1,2}$, TAKUMI KONNO ${ }^{2}$, \\ TAKAYUKI KOHNO $^{2}$, TETSUO HIMI ${ }^{1}$, KEN-ICHI TAKANO ${ }^{1}$ and TAKASHI KOJIMA ${ }^{2}$ \\ Departments of ${ }^{1}$ Otolaryngology, ${ }^{2}$ Cell Science, Research Institute for Frontier Medicine, \\ Sapporo Medical University School of Medicine, Sapporo 060-8556, Japan
}

Received December 27, 2018; Accepted April 7, 2020

DOI: $10.3892 /$ or.2021.7997

\begin{abstract}
In human head and neck squamous cell carcinoma (HNSCC), the invasion and metastatic properties of cancer cells are promoted by junctional adhesion molecule-A (JAM-A) and claudin-1; these are epithelial tight junction molecules regulated by histone deacetylases (HDACs) and transcription factor p63. HDAC expression is reportedly upregulated in HNSCC, and HDAC inhibitors suppress cancer cell proliferation by initiating proliferative arrest or apoptosis. However, little is known of the anti-cancer mechanisms of HDAC inhibitors in HNSCC. Thus, in the present study, the HNSCC Detroit 562 cell line and primary cultured HNSCC cells were treated with HDAC inhibitors to investigate their effects in HNSCC. Higher expression of p63, HDAC1, JAM-A and claudin-1 was observed in HNSCC tissues compared with the adjacent dysplastic regions. In Detroit 562 cells, treatment with trichostatin A (TSA), an inhibitor of HDAC1 and 6, downregulated the expression of p63, JAM-A and claudin-1, and
\end{abstract}

Correspondence to: Professor Takashi Kojima, Department of Cell Science, Research Institute for Frontier Medicine, Sapporo Medical University School of Medicine, South-1, West-17, Chuo-ku, Sapporo 060-8556, Japan

E-mail:ktakashi@sapmed.ac.jp

*Contributed equally

Abbreviations: HNSCC, human head and neck squamous cell carcinoma; JAM-A, junctional adhesion molecule-A; HDAC, histone deacetylase; TSA, torichostatin A; SAHA, suberoylanilide hydroxamic acid; MMP, matrix metalloproteinase; EGFR, epidermal growth factor receptor; PBS, phosphate-buffered saline; TBS, tris-buffered saline; LSR, lipolysis-stimulated lipoprotein receptor

Key words: HDAC inhibitors, head and neck squamous cell carcinoma, JAM-A, claudin-1, p63, EGFR, p21 upregulated that of acetylated tubulin; conversely, p63 knockdown resulted in the downregulation of JAM-A and claudin-1. Collectively, inhibiting HDAC suppressed the migration and invasiveness of cancer cells. In addition, treatment with TSA suppressed cancer cell proliferation via $\mathrm{G}_{2} / \mathrm{M}$ arrest, as well as upregulating p21 and downregulating cyclin D1 expression. TSA also downregulated the expression of epidermal grow th factor receptor (EGFR) and phospho-ERK1/2. p63 knockdown and treatment with an EGFR inhibitor induced $\mathrm{G}_{1}$ arrest and downregulated EGFR and phospho-ERK1/2 levels, respectively. HDAC inhibition also suppressed the migration and invasiveness of primary cultured HNSCC cells. Collectively, the results of the present study indicate that HDAC inhibitors suppress the proliferation, migration and invasiveness of HNSCC by downregulating the p63-mediated tight junction molecules JAM-A and claudin-1, and inducing p63 or p21-mediated growth arrest.

\section{Introduction}

Histone deacetylase (HDAC) is one of the enzymes involved in epigenetic modification, removing acetyl groups from the lysine residues of target proteins. At present, 18 different HDACs have been identified, and are classified as Class I (HDAC 1-3 and 8), class II (HDAC 4-7, 9, and 10), class III (the sirtuin family, SIRT1-7) and class IV (HDAC 11) (1). HDACs serve an important role in the progression of several types of cancer by altering gene expression for differentiation, the cell cycle and apoptosis $(2,3)$.

HDAC upregulation contributes to tumorigenesis in a variety of cancer types, including those of the bladder, breast, lung and colon (4-7). Furthermore, increased expression of HDAC1 and 6 has been observed in human head and neck squamous cell carcinoma (HNSCC), where it was correlated with advanced clinical stage and poor prognosis $(8,9)$. HDAC inhibitors comprise a structurally diverse class of targeted anti-cancer compounds (10). Trichostatin A (TSA), a known class I and II HDAC inhibitor, exerts strong antitumor effects (11). In HNSCC, 
TSA inhibits cell proliferation by inducing cell cycle arrest, apoptosis and the downregulation of stemness genes, such as CD44 and ABCG2 (12). Furthermore, TSA induces $\mathrm{G}_{2} / \mathrm{M}$ cell cycle arrest as well as upregulating p21 expression in colorectal cancer cells (13) and oral squamous cell carcinoma (14). The activation of epidermal growth factor receptor (EGFR) signaling pathways results in $\mathrm{G}_{1} / \mathrm{S}$ cell cycle progression in various types of cancer cell $(15,16)$, and the HDAC inhibitor suberoylanilide hydroxamic acid (SAHA) downregulates EGFR transcription in colorectal cancer cells (17).

The p63 gene, a member of the p53 family, is essential for epithelial development, and the regulation of epithelial cell proliferation and differentiation (18). The p63 gene exists in two distinct isoforms, TAp63 (containing an N-terminal transcription domain) and $\Delta \mathrm{Np} 63$ (lacking the $\mathrm{N}$-terminal transcription domain) (18). p63 is upregulated in $>80 \%$ of all HNSCC tissues (19) and $\Delta \mathrm{Np} 63 \alpha$ serves an important role in HNSCC cell survival, suppressing the $\mathrm{p} 73$-dependent proapoptotic transcriptional program $(20,21)$. The $\Delta \mathrm{Np} 63 \alpha / \mathrm{HDACl} / 2$ complex is also believed to be an essential tumor maintenance factor in SCC (22).

Junctional adhesion molecule-A (JAM-A) is a tight junction molecule which belongs to the IgG superfamily (23). Tight junction molecules are associated with barrier function, but also with cell signaling (24), and the overexpression of JAM-A has been shown to activate Rap1 and $\beta$-1-integrin, inducing cellular migration in breast cancer $(25,26)$. Furthermore, increased JAM-A expression was detected in HNSCC surgical tissues with high expression levels of p63 and $\Delta$ Np63 (27). A significant increase in soluble JAM-A in the sera of patients with HNSCC was also observed, compared with those of healthy subjects. Furthermore, JAM-A siRNA knockdown inhibited the proliferation, migration and invasiveness of HNSCC Detroit 562 cells in vitro; JAM-A overexpression was also found to be regulated via p63 (27).

The bicellular tight junction molecule claudin- 1 is essential for the barrier function of various normal epithelial cells (28). Claudin-1 expression is decreased by transfection of $\Delta \mathrm{Np} 63$ in primary mouse keratinocytes via the claudin-1-promoter region (29). Claudin-1 upregulation was also observed in oral SCC and tonsil SCC tissues, which is associated with advanced clinical stage and surrounding tissue invasion (30-32). In oral SCC cells, claudin-1 promotes cancer cell invasion by upregulating the laminin-5 $\gamma 2$ chain via matrix metalloproteinase (MMP)-2 and membrane-type MMP-1 (33). Increased expression of claudin-1 was also observed, as well as that of tricellular tight junction molecule lipolysis-stimulated lipoprotein receptor (LSR) in HNSCC surgical tissues (34). In the present study, to investigate how HDAC inhibitors influence HNSCC, the HNSCC Detroit 562 cell line and primary cultured HNSCC cells were treated with HDAC inhibitors. HDAC inhibitors suppress the proliferation, migration and invasiveness of HNSCC cells via the downregulation of p63-mediated tight junction molecules, JAM-A and claudin-1, and induction of p21-mediated growth arrest.

\section{Materials and methods}

Reagents and secondary antibodies. Trichostatin A (TSA; cat. no. T8552) was purchased from Sigma-Aldrich;
Merck KGaA. Inhibitors of HDAC1 (cat. no. sc-3523) and HDAC6 (cat. no. sc-223877) were purchased from Santa Cruz Biotechnology, Inc., and the EGFR inhibitor AG1478 (cat. no. 658552) was acquired from Merck KGaA. Alexa Flour 488-conjugated anti-rabbit IgG (cat. no. A32731) and Alexa Flour 594-conjugated anti-mouse IgG (cat. no. A32 742) antibodies were purchased from Molecular Probes; Thermo Fisher Scientific, Inc.

Human tissues. A total of 18 paired head and neck cancer (age, 64.1 \pm 7.4 ; sex, 14 men and 4 women) and adjacent healthy tissues were obtained by tumor resection surgery at the Sapporo Medical University Department of Otolaryngology between January 2015 and December 2018). The present study was approved by the ethics committee of Sapporo Medical University, and written informed consent was obtained from all patients.

Isolation and culture of human head and neck cancer cells. Human head and neck cancer tissues were minced into sections of $2-3 \mathrm{~mm}^{3}$ and washed four times with phosphate-buffered saline (PBS) containing $100 \mathrm{U} / \mathrm{ml}$ penicillin and $100 \mu \mathrm{g} / \mathrm{ml}$ streptomycin. The tissue homogenates were then resuspended in $10 \mathrm{ml}$ Hanks balanced salt solution (Thermo Fisher Scientific, Inc.) containing $0.5 \mu \mathrm{g} / \mathrm{ml}$ DNase I (Sigma-Aldrich; Merck KGaA) and $0.08 \mathrm{mg} / \mathrm{ml}$ Liberase Blendzyme (Roche Diagnostics) in PBS, and then incubated at $37^{\circ} \mathrm{C}$ for $20 \mathrm{~min}$. The incubated specimens were subsequently filtered with 300 and $40-\mu \mathrm{m}$ meshes, centrifuged at $1,200 \mathrm{xg}$ for $3 \mathrm{~min}$, and then cultured in serum-free bronchial epithelial growth medium (Clonetics Corp.) supplemented with $0.5 \mu \mathrm{g} / \mathrm{ml}$ hydrocortisone, $5 \mu \mathrm{g} / \mathrm{ml}$ insulin, $10 \mu \mathrm{g} / \mathrm{ml}$ transferrin, $0.5 \mu \mathrm{g} / \mathrm{ml}$ epinephrine, $6.5 \mu \mathrm{g} / \mathrm{ml}$ triiodothyronine, $50 \mu \mathrm{g} / \mathrm{ml}$ gentamycin, $50 \mu \mathrm{g} / \mathrm{ml}$ amphotericin B, $0.1 \mathrm{ng} / \mathrm{ml}$ retinoic acid, $0.5 \mathrm{ng} / \mathrm{ml} \mathrm{EGF} \mathrm{(Lonza}$ Group, Ltd.) bovine pituitary extract $(1 \% \mathrm{vol} / \mathrm{vol}$, Pel-Freez, LLC), $100 \mathrm{U} / \mathrm{ml}$ penicillin and $100 \mu \mathrm{g} / \mathrm{ml}$ streptomycin (Sigma-Aldrich; Merck KGaA). The primary cultured cells were plated onto $60-\mathrm{mm}$ culture dishes (Corning Inc.), which were precoated with rat tail collagen $(500 \mu \mathrm{g}$ dried tendon $/ \mathrm{ml}$ $0.1 \%$ acetic acid) in a humidified incubator at $37^{\circ} \mathrm{C} 5 \%\left(\mathrm{CO}_{2}\right.$, 95\% air).

Cell cultures and treatment. The pharynx carcinoma Detroit 562 cell line (CCL138) was purchased from the ATCC and cultured in MEM (Sigma-Aldrich; Merck KGaA) supplemented with $10 \%$ fetal bovine serum (FBS; Invitrogen; Thermo Fisher Scientific, Inc.), $100 \mathrm{U} / \mathrm{ml}$ penicillin, $100 \mu \mathrm{g} / \mathrm{ml}$ streptomycin and $50 \mu \mathrm{g} / \mathrm{ml}$ amphotericin B. The cells were plated onto $60-\mathrm{mm}$ culture dishes (Corning Inc.) precoated with rat tail collagen (as aforementioned) and cultured in a humidified incubator at $37^{\circ} \mathrm{C}$. The cells were treated with HDAC inhibitors and an EGFR inhibitor (AG1478) for $24 \mathrm{~h}$.

RNA interference and transfection. An siRNA duplex oligonucleotide against p63 was synthesized by Santa Cruz Biotechnology, Inc. The sequences were as follows: Sense, 5'-GGAAUGACUUCAACUUUGA-3'; and antisense, 5'-UCA AAGUUGAAGUCAUUCC-3'. Detroit 562 cells and primary cancer cells were transfected with $100 \mathrm{nM}$ siRNA against p63 using Lipofectamine ${ }^{\circledR}$ RNAiMAX Reagent (Invitrogen; 
Table I. Antibodies.

\begin{tabular}{|c|c|c|c|c|c|}
\hline \multirow[b]{2}{*}{ Antibody } & \multirow[b]{2}{*}{ Type } & \multicolumn{3}{|c|}{ Dilution factor } & \multirow[b]{2}{*}{ Supplier details } \\
\hline & & IH & IC & WB & \\
\hline Claudin-1 & $\mathrm{pAb}$ & $1: 400$ & $1: 100$ & $1: 1,000$ & Zymed; Thermo Fisher Scientific, Inc. (cat. no. 51-9000) \\
\hline Claudin-7 & $\mathrm{pAb}$ & & & $1: 1,000$ & Zymed; Thermo Fisher Scientific, Inc. (cat. no. 34-9100) \\
\hline Tricellulin & $\mathrm{pAb}$ & & $1: 100$ & $1: 1,000$ & Zymed; Thermo Fisher Scientific, Inc. (cat. no. 48-8400) \\
\hline Occludin & $\mathrm{pAb}$ & & & $1: 1,000$ & Zymed; Thermo Fisher Scientific, Inc. (cat. no. 33-1520) \\
\hline JAM-A & $\mathrm{pAb}$ & $1: 1000$ & $1: 100$ & $1: 1,000$ & Zymed; Thermo Fisher Scientific, Inc. \\
\hline LSR & $\mathrm{pAb}$ & & & $1: 1,000$ & Novus Biologicals, LLC (cat. no. NBP1-89631) \\
\hline Cytokeratin7 & $\mathrm{mAb}$ & & $1: 200$ & $1: 1,000$ & Sigma-Aldrich; Merck KGaA (cat. no. 307M-9) \\
\hline Acetylated tubulin & $\mathrm{mAb}$ & & & $1: 1,000$ & Sigma-Aldrich; Merck KGaA (cat. no. T7451) \\
\hline p63 & $\mathrm{pAb}$ & & $1: 100$ & $1: 1,000$ & Abcam (cat. no. 703809) \\
\hline p63 & $\mathrm{mAb}$ & & $1: 200$ & & OriGene; Technologies, Inc. (cat. no. TA802078) \\
\hline $\mathrm{p} 40(\Delta \mathrm{Np} 63)$ & $\mathrm{mAb}$ & $1: 100$ & & & Nichirei Biosciences Inc. (cat. no. 418171) \\
\hline p21 & $\mathrm{mAb}$ & & & $1: 1,000$ & Invitrogen; Thermo Fisher Scientific, Inc. (cat. no. PA1-30399) \\
\hline Cyclin D1 & $\mathrm{mAb}$ & & & $1: 1,000$ & MBL International Co. (cat. no. MD-17-3) \\
\hline HDAC1 & $\mathrm{pAb}$ & $1: 400$ & $1: 100$ & & Abcam (cat. no. ab7028) \\
\hline Phospho-EGFR & $\mathrm{pAb}$ & & & $1: 1,000$ & Cell Signaling Technology, Inc. (cat. no. 2234) \\
\hline EGFR & $\mathrm{pAb}$ & & & $1: 1,000$ & Cell Signaling Technology, Inc. (cat. no. 4267) \\
\hline Phospho-ERK1/2 & $\mathrm{pAb}$ & & & $1: 1,000$ & Cell Signaling Technology, Inc. (cat. no. 9101) \\
\hline ERK1/2 & $\mathrm{pAb}$ & & & $1: 1,000$ & Promega Corporation (cat. no. V1141) \\
\hline Actin & $\mathrm{pAb}$ & & & $1: 1,000$ & Sigma-Aldrich; Merck KGaA (cat. no. A2066) \\
\hline
\end{tabular}

pAb, rabbit polyclonal antibody; mAb, mouse monoclonal antibody; IH, immunohistochemistry; IC, immunocytochemistry; WB, western blotting; JAM-A, junctional adhesion molecule-A; LSR, lipolysis-stimulated lipoprotein receptor; HDAC, histone deacetylase; EGFR, epidermal growth factor receptor.

Thermo Fisher Scientific, Inc.) $24 \mathrm{~h}$ after plating. A scrambled siRNA sequence (BLOCK-iT Alexa Fluor fluorescent; Invitrogen; Thermo Fisher Scientific, Inc.) was employed as a control siRNA. Experimentation was conducted $48 \mathrm{~h}$ after transfection.

Immunohistochemical analysis of human tissue samples. Human head and neck cancer tissues were fixed with $10 \%$ formalin in PBS at room temperature for least $48 \mathrm{~h}$, and then embedded in paraffin. Briefly, $5-\mu$ m-thick sections were dewaxed in xylene, rehydrated in ethanol, and heated with Vision BioSystems Bond Max using ER2 solution (Leica Microsystems, Inc.) in an autoclave for antigen retrieval. Endogenous peroxidase activity was blocked by incubation with $3 \%$ hydrogen peroxide in methanol for $10 \mathrm{~min}$ at room temperature. The tissue sections were then washed twice with Tris-buffered saline (TBS) and pre-blocked with Block Ace (Bio-Rad Laboratories, Inc.) for $1 \mathrm{~h}$ at room temperature. After washing with TBS, the sections were incubated with anti-p63 (1:200), anti-HDAC1 (1:400), anti-JAM-A (1:1,000) and anti-claudin-1 (1:400) antibodies (Table I) for $1 \mathrm{~h}$ at room temperature. The sections were then washed three times in TBS and incubated using the Vision BioSystems Bond Polymer Refine Detection kit (Leica Microsystems, Inc.). After three washes in TBS, a diamino-benzidine tetrahydrochloride working solution was applied at room temperature. Finally, the sections were counterstained with hematoxylin. A negative control was performed by replacing the primary antibodies with normal rabbit serum (cat. no. ab7487, Abcam). The tissue sections were examined and photographed using an Olympus BX50 microscope with Olympus DP21 digital microscopy camera (Olympus Corporation.

The degree of positive staining was scored from 0 to 3 according to the percentage of atypical cells with positive IHC staining in the observed area: i) $0,0 \%$; ii) $1,1-25 \%$; iii) 2 , 26-50\%; and iv) $3,51-100 \%$. The staining intensity was also graded from 0 to 3 according to the intensity of immunohistochemical staining; i) 0 , none; ii) 1 , low; iii) 2 , moderate; and iv) 3 , high.

Western blot analysis. The cultured cells were scraped from a $35-\mathrm{mm}$ dish containing $400 \mu \mathrm{l}$ of buffer $\left(1 \mathrm{mM} \mathrm{NaHCO}^{3}\right.$ and $2 \mathrm{mM}$ phenylmethylsulfonyl fluoride), collected in microcentrifuge tubes, and then sonicated for $10 \mathrm{sec}$. The protein concentrations of samples were determined using a BCA protein assay reagent kit (Pierce; Thermo Fisher Scientific, Inc.). Aliquots (15 $\mu \mathrm{l}$ of $20 \mu \mathrm{g}$ protein/lane for each sample) were separated by electrophoresis using 5-20\% SDS-PAGE gels (FUJIFILM Wako Pure Chemical Corporation), and electrophoretically transferred onto nitrocellulose membranes (EMD Millipore) The membranes were saturated with blocking buffer (25 mM Tris, pH 8.0, $125 \mathrm{mM} \mathrm{NaCl,} \mathrm{0.1 \%} \mathrm{Tween} 20$ and $4 \%$ skim milk) for $30 \mathrm{~min}$ at room temperature, and then incubated with anti-p63, anti- JAM-A, anti-EGFR, anti-phosphorylated-EGFR, anti-ERK1/2 anti-phosphorylated-ERK1/2, anti-LSR, anti-tricellulin, anti-claudin-1, -4 and -7, 
anti-acetylated-tubulin, anti-cyclin D1, anti-p21 and anti-actin antibodies (all 1:1,000) at room temperature overnight. The antibody details are displayed in Table I. The membranes were then incubated with HRP-conjugated anti-mouse and anti-rabbit IgG antibodies at room temperature for $1 \mathrm{~h}$. The immunoreactive bands were detected using an ECL prime Western blot system (Cytiva), and quantitated by densitometry. The expression levels were normalized to that of actin, and were displayed as bar graphs using Scion Image Beta 4.02 Win (Scion Corporation) (Figs. S2-S6).

Immunocytochemical analysis. Confluent cells cultured in $35-\mathrm{mm}$ glass-bottom dishes (Iwaki) were fixed with cold acetone and ethanol $(1: 1)$ at $-20^{\circ} \mathrm{C}$ for $10 \mathrm{~min}$. After rinsing in PBS, the cells were incubated with anti-cytokeratin 7 (1:200), anti-p63 (1:100), anti $\Delta$ Np63 (1:100), anti-JAM-A (1:100), anti-claudin-1 (1:100), anti-HDAC1(1:100) and anti-tricellulin (1:100) antibodies at room temperature for $1 \mathrm{~h}$ (Table I). Alexa Fluor 488-conjugated anti-rabbit IgG and Alexa Fluor 594-conjugated anti-mouse IgG (Invitrogen; Thermo Fisher Scientific, Inc.) were used as the secondary antibodies (1:200) at room temperature. The specimens were examined using an epifluorescence microscope (Olympus Corporation) and a confocal laser scanning microscope (magnification, x63; LSM5; Zeiss GmbH).

Cell counting. Detroit 562 cells $\left(1 \times 10^{5}\right)$ were plated into $35-\mathrm{mm}$ dishes and cultured for $72 \mathrm{~h}$ until subconfluent at $37^{\circ} \mathrm{C}$. The cultured cells were harvested by trypsinization $(0.25 \%$ Trypsin-EDTA) and resuspended in $2 \mathrm{ml}$ PBS. Subsequently, $450 \mu 1$ Muse ${ }^{\circledR}$ Count \& Viability reagent (Merck Millipore, MA, USA) was added to $50 \mu \mathrm{l}$ from the $2 \mathrm{ml}$ resuspended cells, and incubated for $5 \mathrm{~min}$ at room temperature. The cell counts were determined using the Muse ${ }^{\circledR}$ Cell Analyzer (EMD Millipore) according to the manufacturer's protocol.

Matrigel invasion assay. For invasion assays, Transwell cell culture inserts were used (pore size, $8-\mu \mathrm{m}$; Becton Dickinson and Company). Detroit 562 cells $\left(1 \times 10^{4}\right)$ were seeded at $37^{\circ} \mathrm{C}$ into the upper Matrigel pre-coated chamber (1:50, Becton Dickinson and Company) with serum-free medium at $4^{\circ} \mathrm{C}$ for $30 \mathrm{~min}$, and the lower chamber was filled with human fibroblast conditioned medium containing $10 \mathrm{nM}$ EGF as an adhesive substrate. The cells were incubated for $24 \mathrm{~h}$ at $37^{\circ} \mathrm{C}$. The upper chamber was the fixed with $100 \%$ methanol for $10 \mathrm{~min}$ and stained with Giemsa for $20 \mathrm{~min}$. The number of invading cells was assessed using a microscope imaging system (Olympus Corporation).

Wound-healing assay. Detroit 562 cells and primary cultured HNSCC cells were seeded into $35-\mathrm{mm}$ dishes and cultured in MEM supplemented with 5\% FBS to confluence. A wound was created in each of the cell monolayers using a plastic 200- $\mu 1$ pipette tip, and the wound size was measured at 0 and $24 \mathrm{~h}$ using a microscope imaging system (magnification, $\mathrm{x} 4$; Olympus Corporation).

Cell cycle assay. Detroit 562 cells cultured in $35-\mathrm{mm}$ dishes were harvested using $0.25 \%$ Trypsin-EDTA and washed once with PBS. The cells were slowly added to $1 \mathrm{ml}$ ice cold ethanol
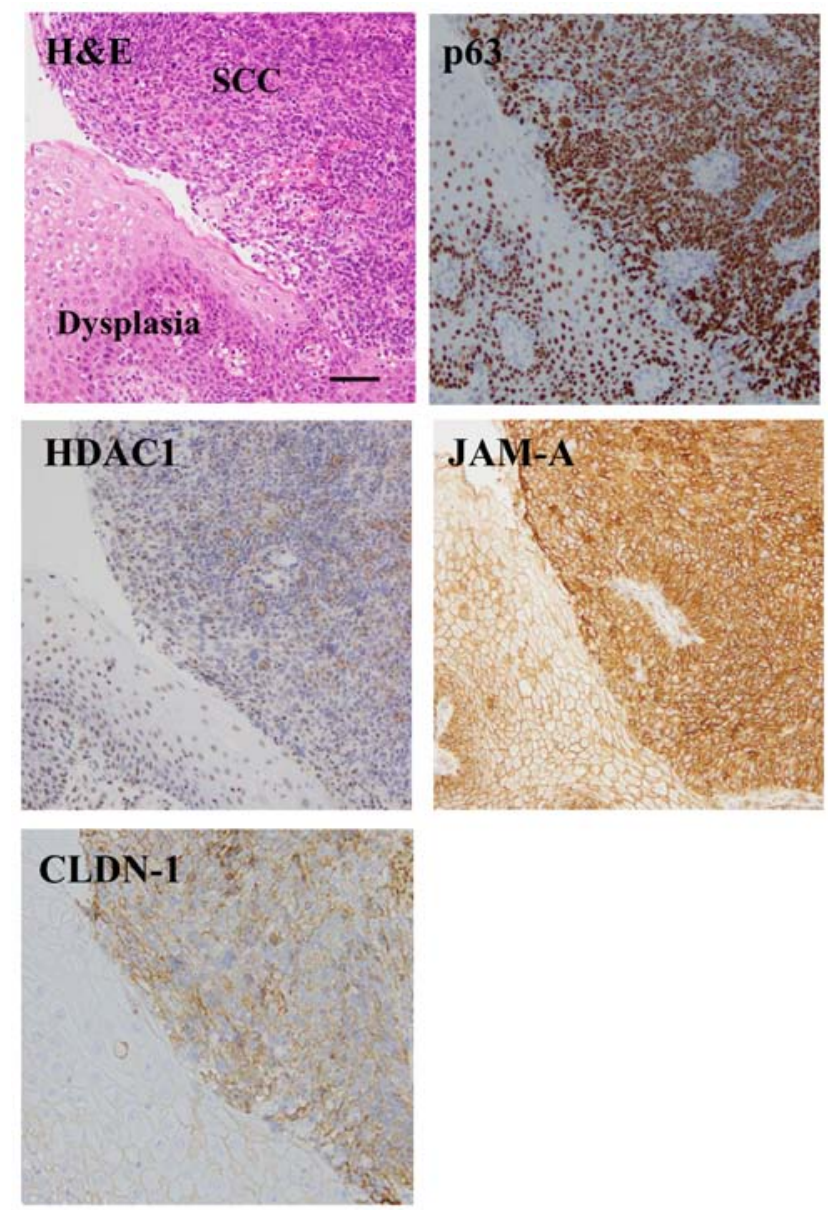

Figure 1. H\&E and immunohistochemical staining of p63, HDAC1, JAM-A and claudin-1 in tissues of patients with human head and neck squamous cell carcinoma, including the adjacent dysplastic regions. Scale bar, $200 \mu \mathrm{m}$ $\mathrm{H} \& \mathrm{E}$, hematoxylin and eosin. HDAC, histone deacetylase; JAM-A, junctional adhesion molecule-A; CLDN-1, claudin-1; SCC, squamous cell carcinoma.

(70\%) and incubated for $\geq 3 \mathrm{~h}$ at $-20^{\circ} \mathrm{C}$. The cells were washed once with PBS, and $200 \mu 1$ Muse $^{\circledR}$ Cell Cycle reagent (EMD Millipore) was added, prior to further incubation for $30 \mathrm{~min}$ at room temperature in the dark. The Muse ${ }^{\circledR}$ Cell Analyzer (EMD Millipore) was then used to assess the cell cycle according to the manufacturer's instructions.

Statistical analysis. Each set of results represents $\geq 3$ separate experiments, and is presented as the mean \pm SEM. Significant differences were determined by one-way ANOVA) with the Tukey-Kramer method. "P<0.05 was considered to indicate a statistically significant difference.

\section{Results}

Expression and localization of p63 and HDAC1 in HNSCC tissues. The expression and localization of p63, HDAC1, JAM-A and claudin-1 in HNSCC surgical tissues was investigated. Using immunohistochemistry, higher expression of $\mathrm{p} 63$, HDAC1, JAM-A and claudin-1 was observed in $83 \%$ of the HNSCC tissue samples (15/18) than in the adjacent dysplastic region (Fig. 1). Furthermore, JAM-A and claudin-1 were expressed at the membranes of cancer cells, whereas p63 and HDAC1 were expressed in the nuclei. 
A

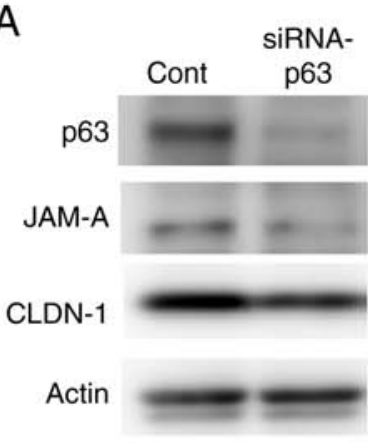

B

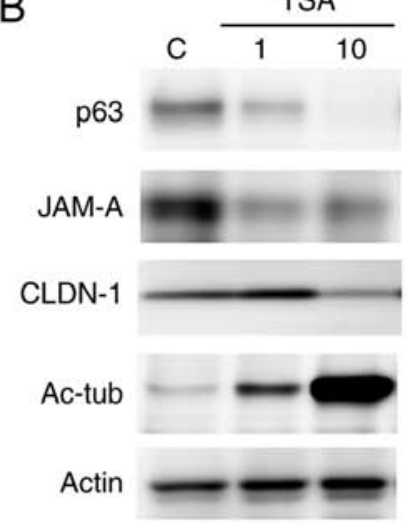

C
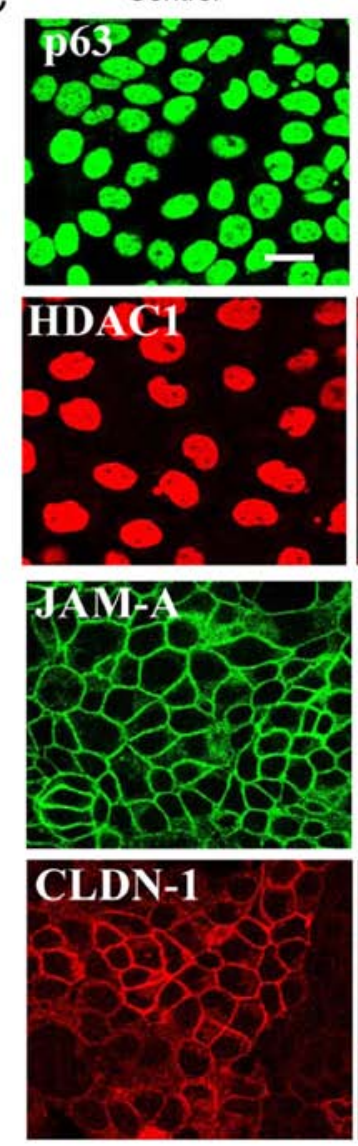

TSA
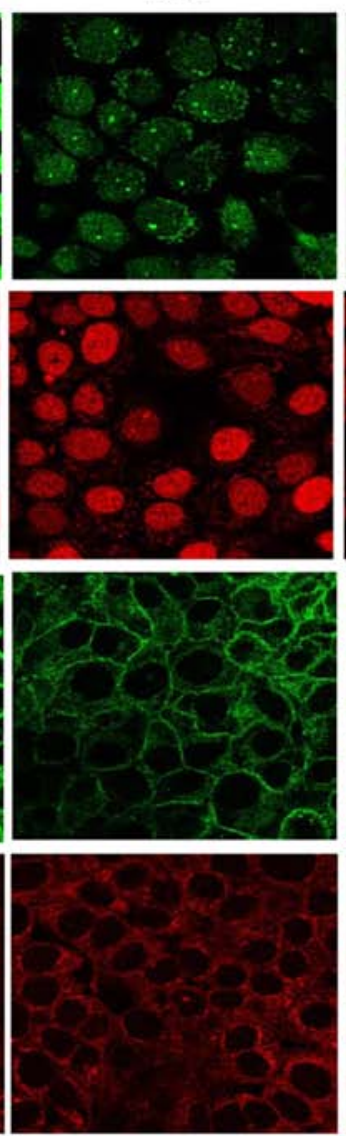

iHDAC1
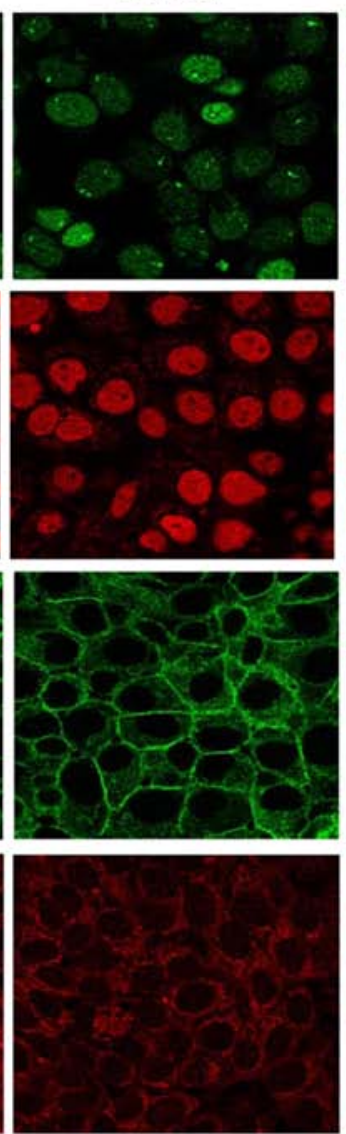
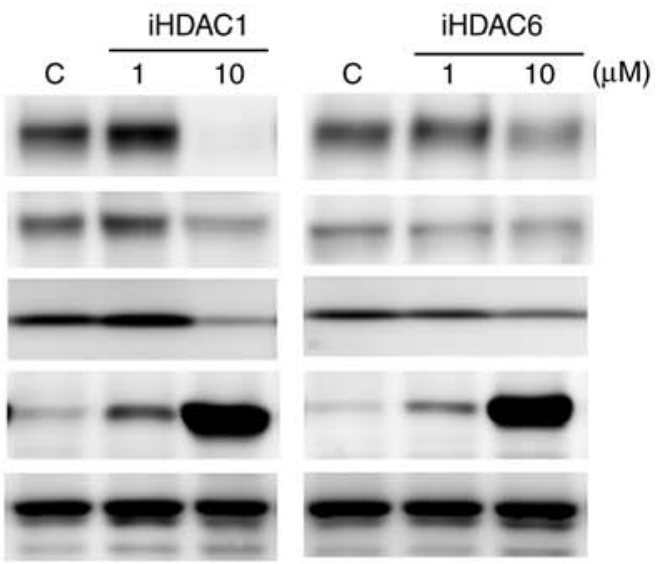

iHDAC6
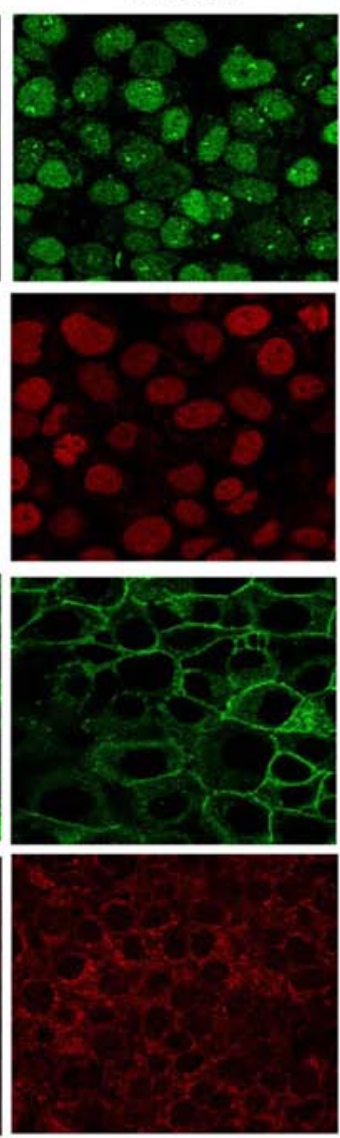

Figure 2. Western blot analysis of p63, JAM-A and claudin-1 expression in Detroit 562 cells (A) transfected with p63 siRNA and (B) treated with HDAC inhibitor TSA, or HDAC1 and 6 inhibitors; 1 and $10 \mu \mathrm{M}$. (C) Immunocytochemical staining for p63, HDAC1, JAM-A and claudin-1 in Detroit 562 cells treated with HDAC inhibitors at $10 \mu \mathrm{M}$. Scale bar, $10 \mu \mathrm{m}$. HDAC, histone deacetylase; iHDAC, HDAC inhibitor; JAM-A, junctional adhesion molecule-A; CLDN-1, claudin-1; Ac-tub, acetylated tubulin; TSA, trichostatin A; siRNA, small interfering RNA; cont, control.

HDAC inhibitors downregulate the expression of JAM-A, claudin-1 and tricellulin in Detroit 562 cells via p63. Western blot analysis revealed that p63 knockdown in Detroit 562 cells resulted in decreased expression of JAM-A and claudin-1, which is in line with previously reported data (27) (Figs. 2A and S2).

To investigate the association between HDAC and p63-mediated tight junction molecules JAM-A and claudin-1 in HNSCC, Detroit 562 cells were treated with the HDAC inhibitor TSA, as well as HDAC1 and 6 inhibitors. As revealed by western blot analysis, expression of p63, HDAC1, JAM-A and claudin-1 was decreased following treatment with all of the HDAC inhibitors in a dose-dependent manner, whereas expression of acetylated tubulin, an effecter of HDAC inhibitors, was increased (Figs. 2B and S2). Immunocytochemical analysis revealed that treatment with $10 \mu \mathrm{M}$ of all HDAC inhibitors decreased the expression of p63, HDAC1, JAM-A and claudin-1 in the nuclei and the cell membrane (Fig. 2C).

The effects of the HDAC inhibitors on the tricellular tight junction molecules tricellulin and LSR in HNSCC were also investigated by western blot analysis. Tricellulin expression was decreased by treatment with all of the HDAC 
A

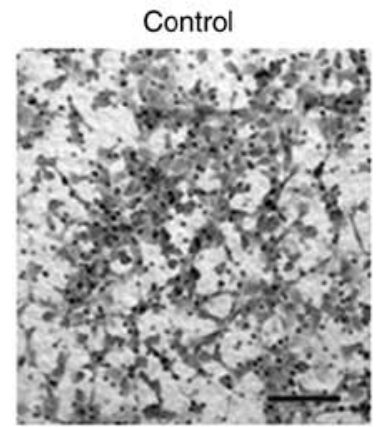

TSA

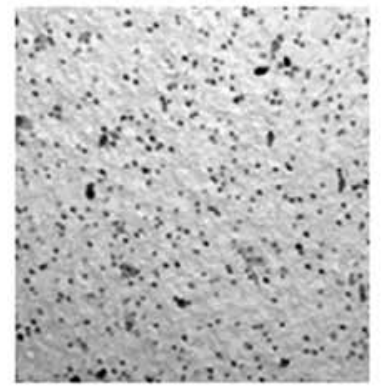

iHDAC1

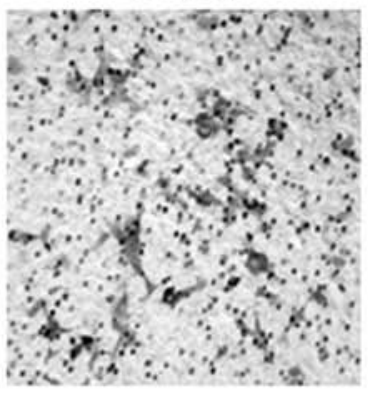

iHDAC6

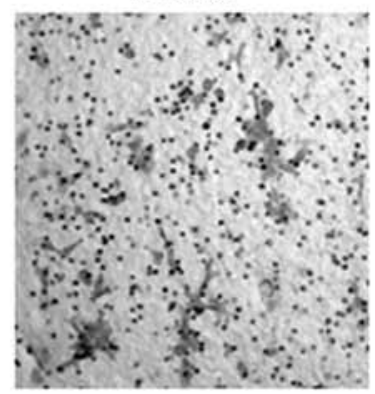

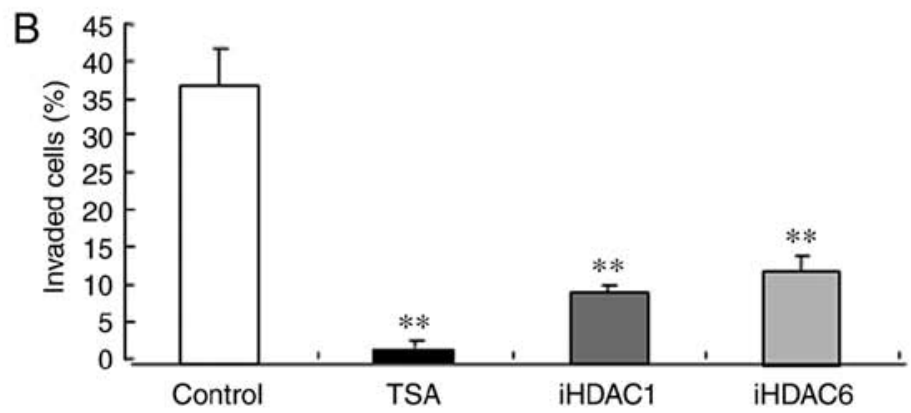

C
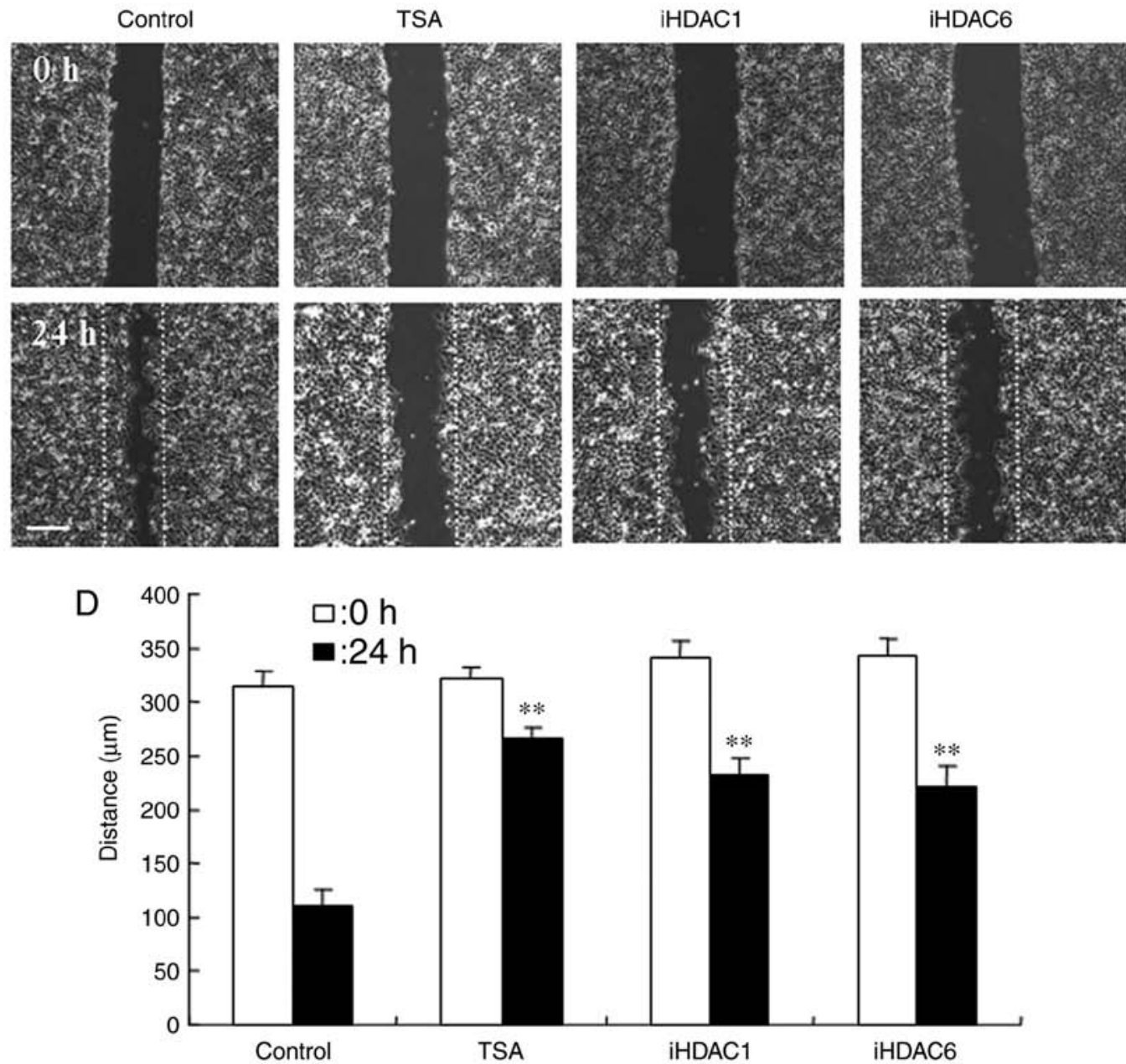

Figure 3. Migration and wound-healing assays. Images of (A) Matrigel invasion and (C) wound-healing assays using Detroit 562 cells treated with the HDAC inhibitor TSA, or HDAC1 and 6 inhibitors; $10 \mu \mathrm{M}$. Scale bar, $200 \mu \mathrm{m}$. (B and D) Quantification of the results of (A) and (C). ** P<0.01 vs. the control. HDAC, histone deacetylase; iHDAC, HDAC inhibitor; TSA, trichostatin A.

inhibitors in a dose-dependent manner, whereas LSR expression was decreased only by treatment with the HDAC1 inhibitor (Figs. S1A and S6). With immunocytochemistry, tricellulin expression was found to be decreased at the cell 


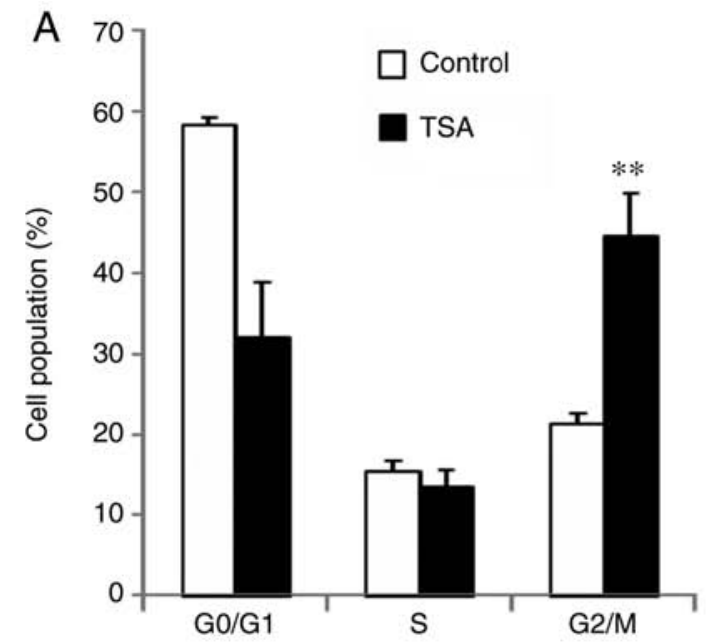

C

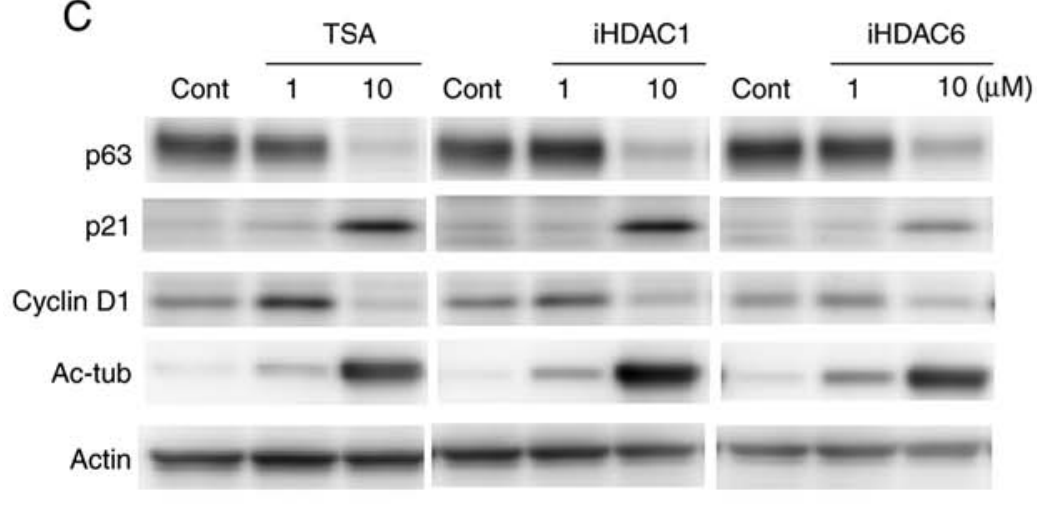

B
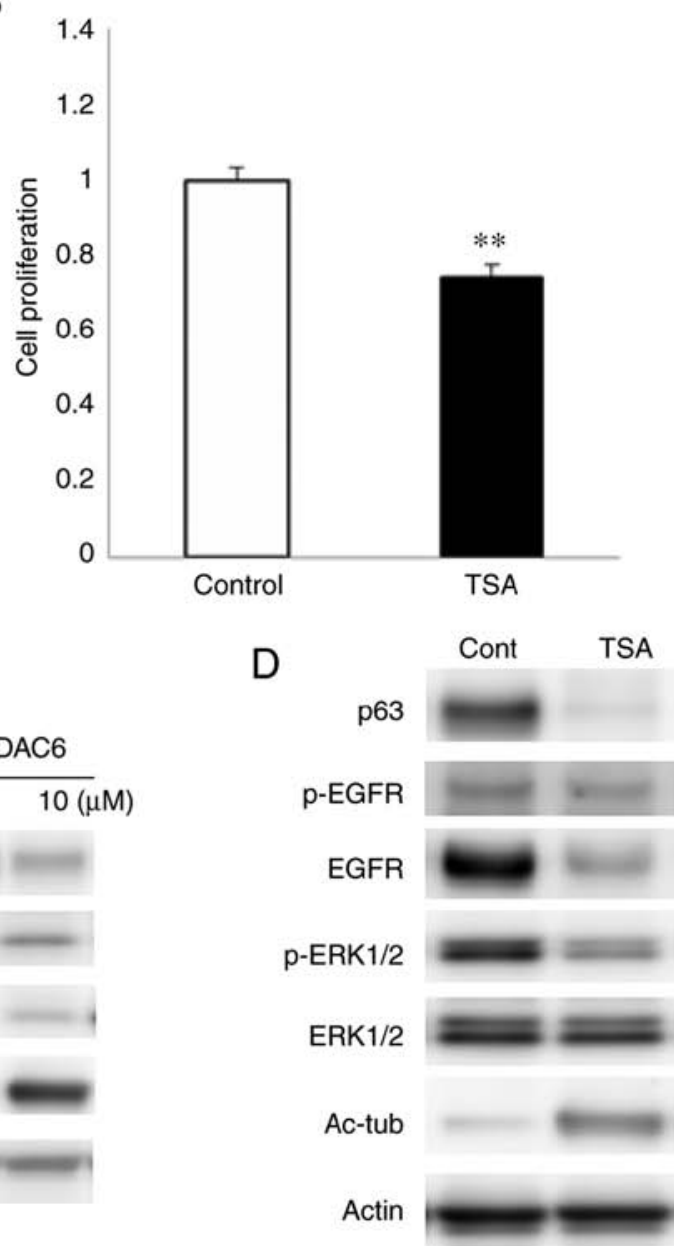

Figure 4. (A) Cell cycle and (B) cell counting assays using Detroit 562 cells treated with TSA at $10 \mu \mathrm{M}$. (C) Western blot analysis for p63, p21 and cyclin D1 in Detroit 562 cells treated with 1 or $10 \mu \mathrm{M}$ HDAC inhibitors. (D) Western blot analysis of p63, EGFR, phosphorylated-EGFR, ERK1/2 and phosphorylated-ERK1/2 in Detroit 562 cells treated with $10 \mu \mathrm{M}$ TSA. ${ }^{* *} \mathrm{P}<0.01$ vs. the control. TSA, trichostatin A; iHDAC, HDAC inhibitor; EGFR, epidermal growth factor receptor; Ac-tub, acetylated tubulin; cont, control.

membranes following treatment with all of the HDAC inhibitors at $10 \mu \mathrm{M}$ (Fig. S1B).

HDAC inhibitors suppress the invasion and migration capacities of Detroit 562 cells. the effects of the HDAC inhibitor TSA, HDAC1 inhibitor, and HDAC6 inhibitor on invasion and migration were investigated using Detroit 562 cells. In the cells treated with $10 \mu \mathrm{M}$, HDAC inhibitors, the numbers of invasive cells were significantly decreased compared with those of the control cells (Fig. 3A and B). For the wound-healing assay, all of the HDAC inhibitors (10 $\mu \mathrm{M}$ each) significantly decreased the wound closure distance, compared with those of the untreated control cells (Fig. 3C and D).

HDAC inhibitors induce $G_{2} / M$ arrest via p21 in Detroit 562 cells. To investigate the cell cycle inhibitory mechanisms of HDAC inhibitors in HNSCC, Detroit 562 cells were treated with TSA, and HDAC1 and 6 inhibitors at $10 \mu \mathrm{M}$ each. Cell cycle analysis revealed that the proportion of cells in the $\mathrm{G}_{2} / \mathrm{M}$ phase was markedly increased by treatment with TSA (Fig. 4A). Cellular proliferation was significantly decreased by TSA (Fig. 4B). In western blot analysis, expression of p21 and acetylated tubulin were markedly upregulated and expression of p63 and cyclinD1 were decreased by all of the HDAC inhibitors (Figs. 4C and S3). Furthermore, expression of EGFR and phosphorylated-ERK1/2 was decreased with downregulation of p63 by treatment with TSA (Figs. 4D and S3).

Downregulation of p63 by TSA induces $G_{I}$ arrest via EGFR in Detroit 562 cells. The effects of p63 expression on cell cycle progression in Detroit 562 cells (via EGFR) were also investigated. Transfection with p63 siRNA increased the proportion of cells in the $G_{0} / G_{1}$ phase (Fig. 5A), and the proliferative capacity of these cells was decreased, compared with the control (Fig. 5B). Western blot analysis revealed that p63 knockdown downregulated EGFR and cyclin D1 expression (Figs. 5C and S4). Treatment with the EGFR inhibitor AG1478 increased the number of cells in the $G_{0} / G_{1}$ phase and inhibited the rate of cellular proliferation (Fig. 5D and E). AG1478 was also found to decrease the level of phosphorylated-ERK1/2 and cyclin D1 (Figs. 5F and S4).

Effects of HDAC inhibitors on primary cultured HNSCC cells. In primary cultured HNSCC cells derived from 

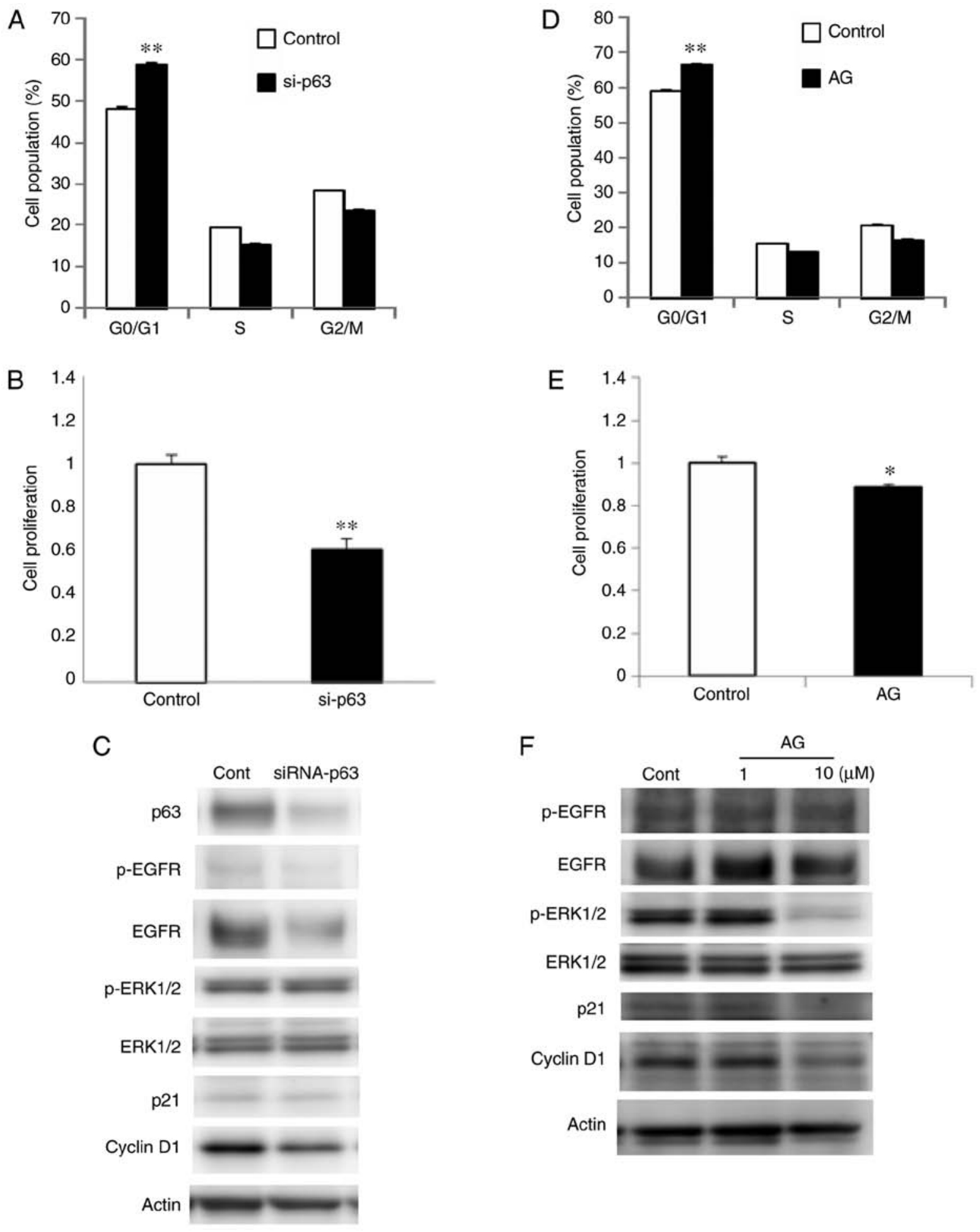

Figure 5. (A) Cell cycle and (B) cell counting assays, (C) and western blot analysis for p63,EGFR, phosphorylated-EGFR, ERK1/2, phosphorylated-ERK1/2,p21 and cyclin D1 in Detroit 562 cells transfected with p63 siRNA. (D) Cell cycle assay, (E) cell counting assay and (F) western blotting for EGFR, phosphorylated-EGFR, ERK1/2, phosphorylated-ERK1/2, p21 and cyclin D1 in Detroit 562 cells treated with the EGFR inhibitor AG1478. ${ }^{*} \mathrm{P}<0.05$ and ${ }^{* *} \mathrm{P}<0.01$ vs. the control. EGFR, epidermal growth factor receptor; siRNA, small interfering RNA; AG, AG1478; cont, control.

surgical tissues, the expression of CK7, p63 and $\triangle \mathrm{Np} 63$ was detected by immunocytochemical analysis (Fig. 6A). Primary cells were treated with TSA, and HDAC1 and 6 inhibitors at $10 \mu \mathrm{M}$ each. Per the phase contrast images, the shape of HNSCC cells changed to an epithelial-like form following treatment with all of the HDAC inhibitors (Fig. 6B). Furthermore, expression of JAM-A and claudin-1 was decreased following treatment with all of the HDAC inhibitors (Figs. 6C, D and S5). Wound-healing assays revealed that HDAC inhibition decreases the wound closure rate, compared that for the untreated control (Fig. 6E and F). Western blot analysis showed that treatment with all of the HDAC inhibitors decreased the expression levels of p63 and cyclin D1, and increased p21 expression (Figs. 6G and S5). 
A

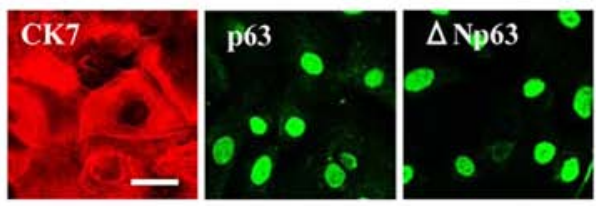

C

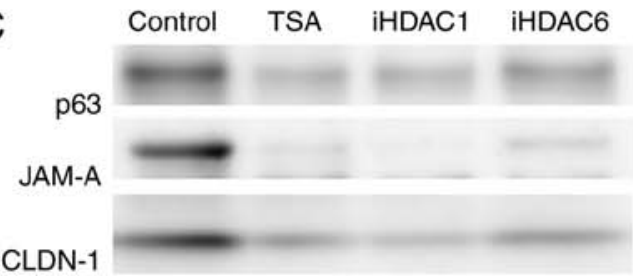

CLDN-1

Ac-tub

Actin

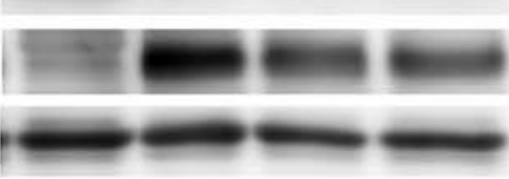

B
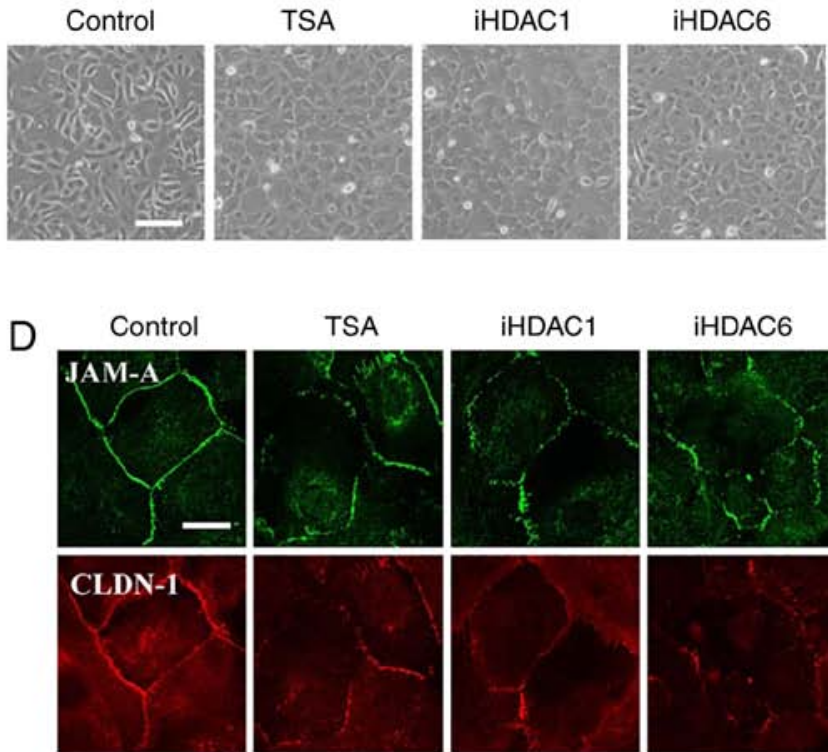

TSA
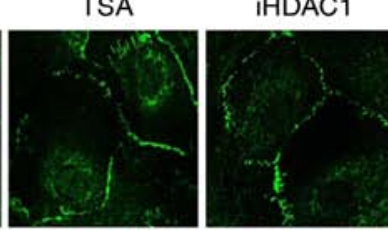

iHDAC6

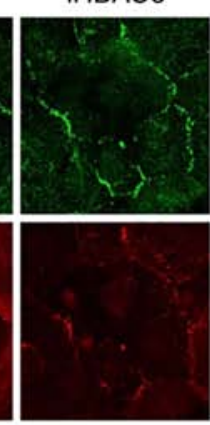

F 400

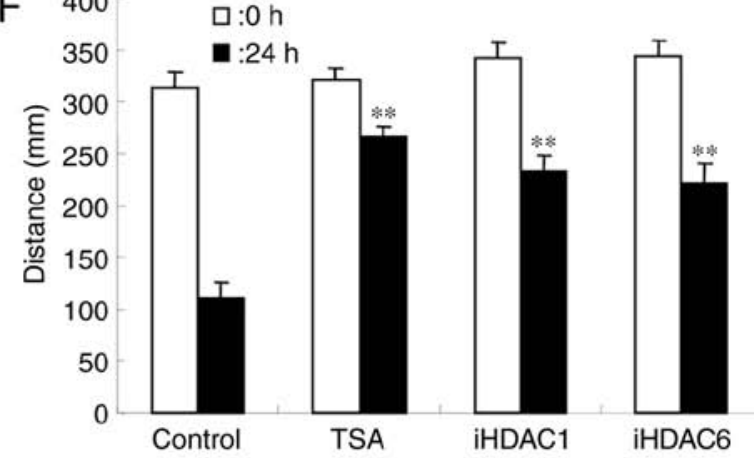

E

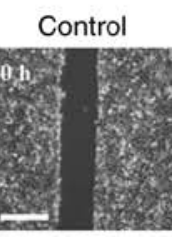

TSA
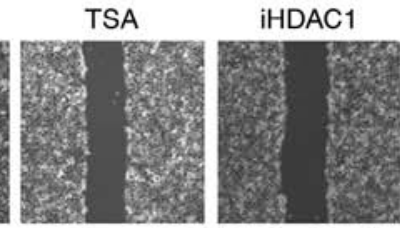

iHDAC6
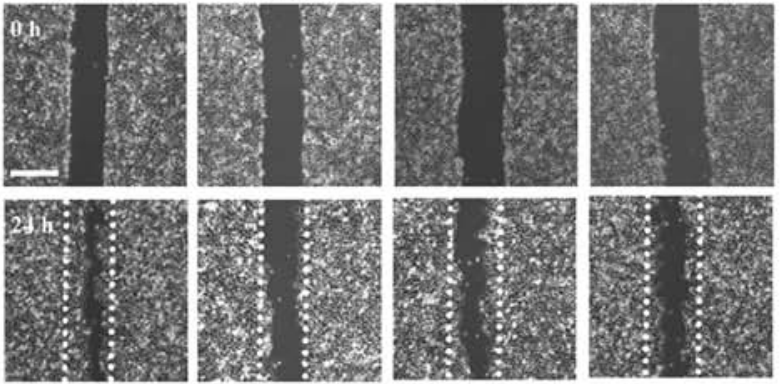

G

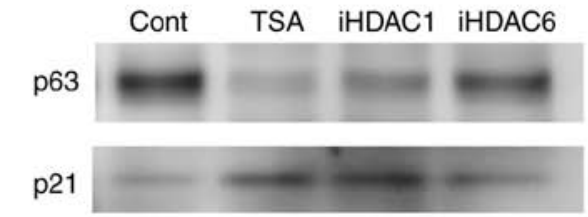

Cyclin D1
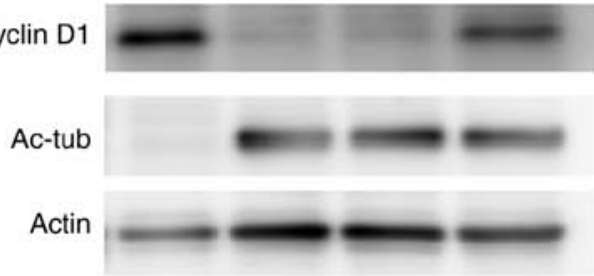

H

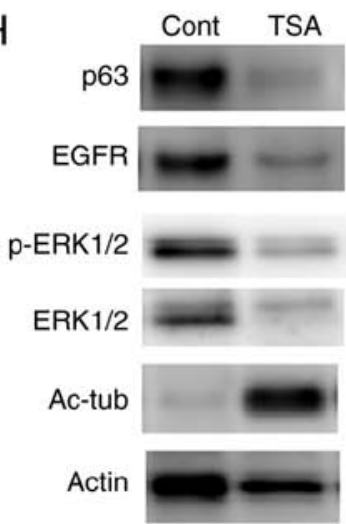

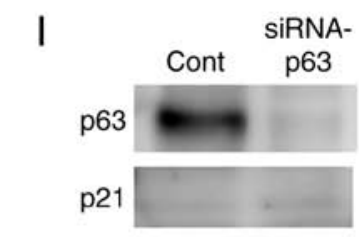

Cyclin D1

Actin

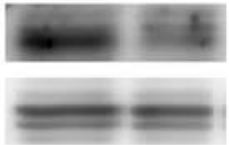

Figure 6. (A) Immunocytochemical staining for CK7, p63 and $\triangle$ Np63 in primary cultured cancer cells derived from human head and neck squamous cell carcinoma tissues. Scale bar, $10 \mu \mathrm{m}$. (B) Phase-contrast images. Scale bar, $50 \mu \mathrm{m}$. (C) Western blotting for p63, JAM-A and claudin-1, and (D) immunocytochemical staining for JAM-A and claudin-1 in primary cultured cancer cells treated with $10 \mu$ M HDAC inhibitors. Scale bar, $10 \mu \mathrm{m}$. (E) Wound-healing assays and (G) western blotting for p63, p21 and cyclin D1 in primary cultured cancer cells treated with HDAC inhibitors at $10 \mu \mathrm{M}$. Scale bar, $200 \mu \mathrm{m}$. (F) Quantification of the results in (E). (H) Western blotting for p63, EGFR, phosphorylated-EGFR, ERK1/2 and phosphorylated-ERK1/2 in primary cultured cancer cells treated with $10 \mu \mathrm{M}$ TSA. (I) Western blotting for p63, p21 and cyclin D1 in primary cultured cancer cells transfected with p63siRNA of. ** $\mathrm{P}<0.01$ vs. the control. CK7, anti-cytokeratin 7; HDAC, histone deacetylase; iHDAC, HDAC inhibitor; JAM-A, junctional adhesion molecule-A; CLDN-1, claudin-1; Ac-tub, acetylated tubulin; TSA, trichostatin A; siRNA, small interfering RNA; cont, control.

Furthermore, treatment with TSA not only decreased p63 expression, but also that of EGFR, phosphorylated-ERK1/2 and ERK1/2 (Figs. 6H and S5). When primary cultured HNSCC cells were transfected with p63 siRNA, the expression of p63 and cyclin D1 was also decreased, as evidenced by western blot analysis (Figs. 6I and S5).

\section{Discussion}

There is growing interest in the potential clinical use of HDAC inhibitors as a novel class of targeted cancer therapeutics. In the present study, the effects of HDAC inhibitors were investigated in HNSCC; higher expression levels of p63, HDAC1, JAM-A 
and claudin-1 were observed in HNSCC tissues than in the adjacent dysplastic regions. The HDAC inhibitor TSA, and specific inhibitors of HDAC1 and 6 suppressed the proliferation, migration and invasiveness of HNSCC by downregulating p63-mediated tight junction molecules JAM-A and claudin-1, and inducing p63- and p21-mediated proliferation arrest. In the present study, wound-healing assays were used to indicate the migration of HNSCC cells. Although wound-healing assays are generally conducted with serum-free medium, Detroit 562 cells are sensitive to changes in serum concentration. Accordingly, $5 \%$ FBS was used, which was acknowledged as a study limitation.

The upregulation of JAM-A and claudin-1 correlates with tumor progression in various cancer types (35). JAM-A upregulation induces cancer cell migration by activating Rap1 and $\beta$-1-integrin in breast cancer (25). Furthermore, high expression levels of JAM-A positively correlate with poor prognosis in patients with nasopharyngeal carcinoma (NPC), and induces the epithelial-to-mesenchymal transition of NPC cells via the PI3K/Akt pathway (36). JAM-A expression also promotes proliferation and inhibits apoptosis in both gastric and lung cancer cells $(37,38)$.

JAM-A is dysregulated via p63/GATA-3 in HNSCC (27). Furthermore, downregulation of JAM-A by p63 knockdown inhibits the migratory and invasive capacities of HNSCC cells (27). On the other hand, increased expression of claudin-1 is associated with advanced clinical stage and invasive pathologic characteristics of oral SCC (30-32); claudin-1 overexpression upregulates the laminin-5 $\gamma 2$ chain via MMP-2 and membrane-type MMP-1, and induces cancer cell invasion in oral SCC (33). Claudin-1 is also a target gene of p63 in epithelial cells (29), and HDAC inhibitors decrease the stability and expression of claudin-1 mRNA and reduce colonic cancer cell invasiveness (39). HDAC1 and 2 directly mediate the repressive functions of p63 (40). HDAC inhibitors are also believed to partially inhibit the migration and invasiveness of HNSCC cells via JAM-A and claudin-1 downregulation in p63-dependent and -independent manners.

JAM-A is a reovirus receptor that controls the entry of the virus into cells (41). The reovirus-based formulation Reolysin is an oncolytic virus that is naturally genetically modified to selectively infect and kill cancer cells, and is being evaluated as an anticancer therapy for advanced multiple myeloma via the overexpression of JAM-A (42). Notably, HDAC inhibitors increase the entry and replication of the reovirus into HNSCC cells, and combination treatment with HDAC inhibitors and Reolysin increases both the cytotoxic effects of the reovirus and anti-tumor immunity; however, the mechanisms involving JAM-A remain unclear (43).

Tricellulin and LSR are tricellular tight junction molecules (44). In HNSCC, tricellulin is weakly expressed, as is claudin-7, whereas LSR and claudin-1 are highly expressed $(32,34)$. siRNA knockdown of LSR, but not tricellulin, markedly increases the invasiveness of Detroit 562 cells and primary cultured HNSCC cells (34). In the present study, tricellulin expression was decreased by all of the HDAC inhibitors tested in a dose-dependent manner, as were the levels of p63 and acetylated tubulin, whereas LSR expression was decreased only by treatment with the HDAC1 inhibitor (Fig. S1A). In immunocytochemistry, tricellulin was demonstrated to be decreased at the membranes by treatment with all of the HDAC inhibitors (Fig. S1B). However, the roles of tricellular tight junction molecules remain unclear in HNSCC.

HDAC inhibitors promote proliferative arrest, differentiation and apoptosis in tumor cells with minimal effects on normal tissue (45). Moreover, TSA has been shown to induce the upregulation of $\mathrm{p} 21$ and $\mathrm{G}_{2} / \mathrm{M}$ cell cycle arrest in colorectal cancer and oral SCC $(13,14)$. Class 1 HDACs inhibit p21 expression, and knockdown of HDAC1, 2 and 3 upregulates p21 promoter activity in human colon cancer cells (37). The cell cycle of the HNSCC Detroit 562 cell line is affected by various factors $(46,47)$. Furthermore, the HDAC inhibitor SAHA causes cell cycle arrest by upregulating cyclin-dependent kinase inhibitor 1 and downregulating G1/S-specific cyclin-D1 (encoding p21 and cyclin D1 proteins), as well as inhibiting larynx cancer cell proliferation (48).

The EGFR-ERK signaling pathway is associated with $\mathrm{G}_{1} / \mathrm{S}$ cell cycle progression in cancer cells $(15,16)$. In the present study, treatment with TSA also downregulated the expression of p63, EGFR and phospho-ERK1/2 in HNSCC cells. Furthermore, p63 knockdown or treatment with the EGFR inhibitor AG1478 induced $\mathrm{G}_{1}$ arrest and the downregulation of p63, EGFR, phospho-ERK1/2 and cyclin D1, without upregulating of $\mathrm{p} 21$. These findings indicate that TSA suppresses cancer cell proliferation via p63-mediated $\mathrm{G}_{1}$ arrest in HNSCC.

In conclusion, the HDAC inhibitor TSA, as well as specific inhibitors of HDAC1 and 6, suppresses the proliferation, migration and invasiveness of HNSCC cells by downregulating p63-mediated tight junction molecules JAM-A and claudin-1, and inducing p63- or p21-mediated growth arrest with single-agent activity. HDAC inhibitors are considered to be potential immunomodulatory agents for cancer therapy. HDAC6 is a unique member of the HDAC family that not only participates in histone acetylation and deacetylation, but also targets several nonhistone substrates and upregulates several critical immune factors, such as programmed death receptor-1 and programmed death receptor ligand-1 (which are major targets for cancer immunotherapy) (49). HDAC inhibitors are an important emerging therapy with single-agent activity against multiple cancer types and have significant potential in combination therapy. Thus the findings of the present study may provide an improved understanding of the mechanisms by which HDAC inhibition suppresses head and neck cancers, and thus promote a novel form of cancer therapy.

\section{Acknowledgements}

Not applicable.

\section{Funding}

The present study was supported by the Ministry of Education, Culture, Sports, Science, and Technology of Japan (grant no. 19K07464).

\section{Availability of data and materials}

The datasets used and/or analyzed during the current study are available from the corresponding author upon reasonable request. 


\section{Authors' contributions}

AKa, KOh, TH, KT and TKoj designed the study. TKa, MK, AKo, YM KOba, KN, RM, YK, TKon and TKoh analyzed the data. AKa, KOha, TH, KT and TKoj wrote the manuscript. All authors read and approved the final manuscript.

\section{Ethics approval and consent to participate}

The present study was approved by the ethics committee of Sapporo Medical University, and informed consent was obtained from all patients.

\section{Patient consent for publication}

Not applicable.

\section{Competing interests}

The authors declare that they have no competing interests.

\section{References}

1. Seto E and Yoshida M: Erasers of Histone Acetylation. The Histone Deacetylase Enzymes. Cold Spring Harb Perspect Biol 6: a018713, 2014

2. Marks P, Rifkind RA, Richon VM, Breslow R, Miller T and Kelly WK: Histone deacetylases and cancer: Causes and therapies. Nat Rev Cancer 1: 194-202, 2001.

3. Ropero S and Esteller M: The role of histone deacetylases (HDACs) in human cancer. Mol. Oncol 1: 19-25, 2007.

4. Juengel E, Meyer dos Santos S, Schneider T, Makarevic J, Hudak L, Bartsch G, Haferkamp A, Wiesner C and Blaheta RA: HDAC inhibition suppresses bladder cancer cell adhesion to collagen under flow conditions. Exp Biol Med (Maywood) 238: 1297-1304, 2013.

5. Munster PN, Troso-Sandoval T, Rosen N, Rifkind R, Marks PA and Richon VM: The histone deacetylase inhibitor suberoylanilide hydroxamic acid induces differentiation of human breast cancer cells. Cancer Res 61: 8492-8497, 2001.

6. Komatsu N, Kawamata N, Takeuchi S, Yin D, Chien W, Miller CW and Koeffler HP: SAHA, a HDAC inhibitor, has profound anti-growth activity against non-small cell lung cancer cells. Oncol Rep 15: 187-191, 2006.

7. Wilson AJ, Byun DS, Popova N, Murray LB, L'Italien K, Sowa Y, Arango D, Velcich A, Augenlicht LH and Mariadason JM: Histone deacetylase 3 (HDAC3) and other class I HDACs regulate colon cell maturation and p21 expression and are deregulated in human colon cancer. J Biol Chem 281: 13548-13558, 2006.

8. Sakuma T, Uzawa K, Onda T, Shiiba M, Yokoe H, Shibahara T and Tanzawa H: Aberrant expression of histone deacetylase 6 in oral squamous cell carcinoma. Int J Oncol 29: 117-124, 2006

9. Zhao R, Chen K, Cao J, Yu H, Tian L and Liu M: A correlation analysis between HDAC1 over-expression and clinical features of laryngeal squamous cell carcinoma. Acta Otolaryngol 136: $172-176,2016$

10. de Ruijter AJ, van Gennip AH, Caron HN, Kemp S and van Kuilenburg AB: Histone deacetylases (HDACs): Characterization of the classical HDAC family. Biochem J 370: 737-749, 2003.

11. Khan N, Jeffers M, Kumar S, Hackett C, Boldog F, Khramtsov N, Qian X, Mills E, Berghs SC, Carey N, et al: Determination of the class and isoform selectivity of small-molecule histone deacetylase inhibitors. Biochem J 409: 581-589, 2008.

12. Chikamatsu K, Ishii H, Murata T, Sakakura K, Shino M, Toyoda M, Takahashi K and Masuyama K: Alteration of cance stem cell-like phenotype by histone deacetylase inhibitors in squamous cell carcinoma of the head and neck. Cancer Sci 104: $1468-1475,2013$

13. Meng J, Zhang HH, Zhou CX, Li C, Zhang F and Mei QB: The histone deacetylase inhibitor trichostatin A induces cell cycle arrest and apoptosis in colorectal cancer cells via p53-dependent and -independent pathways. Oncol Rep 28: 384-388, 2012.
14. Anh TD, Ahn MY, Kim SA, Yoon JH and Ahn SG: The histone deacetylase inhibitor, Trichostatin A, induces $\mathrm{G} 2 / \mathrm{M}$ phase arrest and apoptosis in YD-10B oral squamous carcinoma cells. Oncol Rep 27: 455-460, 2012.

15. Massagué J: G1 cell-cycle control and cancer. Nature 432: 298-306, 2004.

16. Zhang W and Liu HT: MAPK signal pathways in the regulation of cell proliferation in mammalian cells. Cell Res 12: 9-18, 2002.

17. Chou CW, Wu MS, Huang WC and Chen CC: HDAC inhibition decreases the expression of EGFR in colorectal cancer cells. PLoS One 6: e18087, 2011.

18. Koster MI, Kim S, Mills AA, DeMayo FJ and Roop DR: p63 is the molecular switch for initiation of an epithelial stratification program. Genes Dev 18: 126-131, 2004.

19. Weber A, Bellmann U, Bootz F, Wittekind C and Tannapfel A: Expression of p53 and its homologues in primary and recurrent squamous cell carcinomas of the head and neck. Int J Cancer 99 22-28, 2002.

20. Rocco JW, Leong CO, Kuperwasser N, DeYoung MP and Ellisen LW: p63 mediates survival in squamous cell carcinoma by suppression of p73-dependent apoptosis. Cancer Cell 9: 45-56, 2006.

21. DeYoung MP, Johannessen CM, Leong CO, Faquin W, Rocco JW and Ellisen LW: Tumor-specific p73 up-regulation mediates p63 dependence in squamous cell carcinoma. Cancer Res 66: 9362-9368, 2006.

22. Ramsey MR, He L, Forster N, Ory B and Ellisen LW: Physical association of HDAC1 and HDAC2 with p63 mediates transcriptional repression and tumor maintenance in squamous cell carcinoma. Cancer Res 71: 4373-4379, 2011.

23. Martìn-Padura I, Lostaglio S, Schneemann M, Williams S, Romano M, Fruscella P, Panzeri C, Stoppacciaro A, Ruco L, Villa A, et al: Junctional adhesion molecule, a novel member of the immunoglobulin superfamily that distributes at intercellular junctions and modulates monocyte transmigration. J Cell Biol 142: 117-127, 1998.

24. Tsukita S, Furuse M and Itoh M: Multifunctional strands in tight junctions. Nat Rev Mol Cell Biol 2: 285-293, 2001.

25. McSherry EA, Brennan K, Hudson L, Hill ADK and Hopkins AM: Breast cancer cell migration is regulated through junctional adhesion molecule-A-mediated activation of Rap1 GTPase. Breast Cancer Res 13: R31, 2011.

26. Severson EA, Lee WY, Capaldo CT, Nusrat A and Parkos CA Junctional adhesion molecule A interacts with Afadin and PDZ-GEF2 to activate Rap1A, regulate beta1 integrin levels, and enhance cell migration. Mol Biol Cell 20: 1916-1925, 2009.

27. Kakuki T, Kurose M, Takano K, Kondoh A, Obata K, Nomura K, Miyata R, Kaneko Y, Konno T, Takahashi S, et al: Dysregulation of junctional adhesion molecule-A via p63/GATA-3 in head and neck squamous cell carcinoma. Oncotarget 7: 33887-33900, 2016.

28. Furuse M, Hata M, Furuse K, Yoshida Y, Haratake A, Sugitani Y, Noda T, Kubo A and Tsukita S: Claudin-based tight junctions are crucial for the mammalian epidermal barrier: A lesson from claudin-1-deficient mice. J Cell Biol 156: 1099-1111, 2002.

29. Lopardo T, Lo Iacono N, Marinari B, Giustizieri ML, Cyr DG, Merlo G, Crosti F, Costanzo A and Guerrini L: Claudin-1 is a p63 target gene with a crucial role in epithelial development. PLoS One 3: e2715, 2008.

30. Dos Reis PP, Bharadwaj RR, Machado J, Macmillan C, Pintilie M, Sukhai MA, Perez-Ordonez B, Gullane P, Irish J and Kamel-Reid S: Claudin 1 overexpression increases invasion and is associated with aggressive histological features in oral squamous cell carcinoma. Cancer 113: 3169-3180, 2008.

31. Sappayatosok K and Phattarataratip E: Overexpression of Claudin- 1 is associated with advanced clinical stage and invasive pathologic characteristics of oral squamous cell carcinoma. Head Neck Pathol 9: 173-180, 2015.

32. Kondoh A, Takano K, Kojima T, Ohkuni T, Kamekura R, Ogasawara N, Go M, Sawada N and Himi T: Altered expression of claudin-1, claudin-7, and tricellulin regardless of human papilloma virus infection in human tonsillar squamous cell carcinoma. Acta Otolaryngol 131: 861-868, 2011.

33. Oku N, Sasabe E, Ueta E, Yamamoto T and Osaki T: Tight junction protein claudin-1 enhances the invasive activity of oral squamous cell carcinoma cells by promoting cleavage of laminin-5 gamma 2 chain via matrix metalloproteinase (MMP)-2 and membrane-type MMP-1. Cancer Res 66: 5251-5257, 2006. 
34. Takano K, Kakuki T, Obata K, Nomura K, Miyata R, Kondo A, Kurose M, Kakiuchi A, Kaneko Y, Kohno T, et al: The behavior and role of lipolysis-stimulated lipoprotein receptor, a component of tricellular tight junctions, in head and neck squamous cell carcinomas. Anticancer Res 36: 5895-5904, 2016.

35. Leech AO, Cruz RG, Hill AD and Hopkins AM: Paradigms lost-an emerging role for over-expression of tight junction adhesion proteins in cancer pathogenesis. Ann Trans Med 3: 184, 2015.

36. Tian Y, Tian Y, Zhang W, Wei F, Yang J, Luo X, Zhou T, Hou B, Qian S, Deng X, et al: Junctional adhesion molecule-A, an epithelial-mesenchymal transition inducer, correlates with metastasis and poor prognosis in human nasopharyngeal cancer. Carcinogenesis 36: 41-48, 2015.

37. Zang M, Luo W, Huang B, Liu Z, Sun L, Zhang Q, Qiu X, Xu K and Wang E: Overexpression of JAM-A in non-small cell lung cancer correlates with tumor progression. PLoS One 8: e79173, 2013.

38. Ikeo K, Oshima T, Shan J, Matsui H, Tomita T, Fukui H, Watari $J$ and Miwa H: Junctional adhesion molecule-A promotes proliferation and inhibits apoptosis of gastric cancer. Hepatogastroenterology 62: 540-545, 2015.

39. Krishnan M, Singh AB, Smith JJ, Sharma A, Chen X, Eschrich S, Yeatman TJ, Beauchamp RD and Dhawan P: HDAC inhibitors regulate claudin-1 expression in colon cancer cells through modulation of mRNA stability. Oncogene 29: 305-312, 2010.

40. LeBoeuf M, Terrell A, Trivedi S, Sinha S, Epstein JA, Olson EN, Morrisey EE and Millar SE: Hdac1 and Hdac2 act redundantly to control p63 and p53 functions in epidermal progenitor cells. Dev Cell 19: 807-818, 2010.

41. Barton ES, Forrest JC, Connolly JL, Chappell JD, Liu Y, Schnell FJ, Nusrat A, Parkos CA and Dermody TS: Junction adhesion molecule is a receptor for reovirus. Cell 104: 441-451, 2001.
42. Kelly KR, Espitia CM, Zhao W, Wendlandt E, Tricot G, Zhan F, Carew JS and Nawrocki ST: Junctional adhesion molecule-A is overexpressed in advanced multiple myeloma and determines response to oncolytic reovirus. Oncotarget 6: 41275-41289, 2015.

43. Jaime-Ramirez AC, Yu JG, Caserta E, Yoo JY, Zhang J, Lee TJ, Hofmeister C, Lee JH, Kumar B, Pan Q, et al: Reolysin and histone deacetylase inhibition in the treatment of head and neck squamous cell carcinoma. Mol Ther Oncolytics 5: 87-96, 2017.

44. Masuda S, Oda Y, Sasaki H, Ikenouchi J, Higashi T, Akashi M, Nishi $\mathrm{E}$ and Furuse M: LSR defines cell corners for tricellular tight junction formation in epithelial cells. J Cell Sci 124: 548-555, 2011.

45. Lane AA and Chabner BA: Histone deacetylase inhibitors in cancer therapy. J Clin Oncol 27: 5459-5468, 2009.

46. Wang H, Xue W and Jiang X: Overexpression of TRIM24 stimulates proliferation and glucose metabolism of head and neck squamous cell carcinoma. Biomed Res Int 2018: 6142843, 2018.

47. Dziedzic A, Kubina R, Kabała-Dzik A and Tanasiewicz M: Induction of cell cycle arrest and apoptotic response of head and neck squamous carcinoma cells (Detroit 562) by caffeic acid and aaffeic acid phenethyl ester derivative. Evid Based Complement Alternat Med 2017: 6793456, 2017.

48. Grabarska A, Łuszczki JJ, Nowosadzka E, Gumbarewicz E, Jeleniewicz W, Dmoszyńska-Graniczka M, Kowalczuk K, Kupisz K, Polberg K and Stepulak A: Histone deacetylase inhibitor SAHA as potential targeted therapy agent for larynx cancer cells. J Cancer 2017 8: 19-28, 2017.

49. Li T, Zhang C, Hassan S, Liu X, Song F, Chen K, Zhang W and Yang J: Histone deacetylase 6 in cancer. J Hematol Oncol 11: 111, 2018.

This work is licensed under a Creative Commons Attribution-NonCommercial-NoDerivatives 4.0 International (CC BY-NC-ND 4.0) License. 